\title{
Determinants of over and underuse of caesarean births in the Eastern Mediterranean Region: an updated review
}

\author{
Bismeen Jadoon, ${ }^{1}$ Ramez Mahaini ${ }^{1}$ and Karima Gholbzouri ${ }^{1}$
}

${ }^{1}$ World Health Organization Regional Office for the Eastern Mediterranean, Cairo, Egypt (Correspondence to: B. Jadoon: bismeen.jadoon@gmail.com).

\begin{abstract}
Background: The World Health Organization (WHO) Eastern Mediterranean Region shows a huge disparity in caesarean birth practice among its 22 Member States. Little research has been conducted at the Regional level to determine the underlying causes.
\end{abstract}

Aims: This study aimed at exploring the available evidence on key determinants of high and low caesarean birth rates in the Region.

Methods: A scoping literature review was performed. We searched PubMed and Medline with keywords "determinants of caesarean birth/caesarean section" and "caesarean birth/caesarean section trend" in the Region during 2000-2017. We included cohort studies, case-control studies, systematic reviews and reviews published in peer-reviewed journals. Latest data about demographics and socioeconomic indicators of maternal and child health care were extracted from demographic health surveys and situational analyses from Member States and WHO Statistics 2015. Fifty-seven of 395 studies met the inclusion criteria. These determinants were discussed in a conceptual framework based on Andersen's Behavioral Model of Health Services Use, 2001.

Results: Lack of access to facility-based delivery and absence of skilled birth attendants were mainly responsible for the low caesarean birth rate in the Region. Social, cultural, individual and institutional factors affecting women's choice for childbirth have contributed to the high caesarean birth rate.

Conclusion: A multidimensional approach is required to explore these determinants to optimize the Regional caesarean birth rate. Further qualitative studies are needed to investigate how these factors affect choice of birthing process in specific cultural settings in the Region.

Citation: Jadoon B; Mahaini R; Gholbzouri K. Determinants of over and underuse of caesarean births in the Eastern Mediterranean Region: an updated review. East Mediterr Health J. 2019;25(11):837-846. https://doi.org/10.26719/emhj.19.033

Received: 22/10/17; accepted: 05/07/18

Copyright @ C World Health Organization (WHO) 2019. Some rights reserved. This work is available under the CC BY-NC-SA 3.o IGO license https:// creativecommons.org/licenses/by-nc-sa/3.o/igo

\section{Introduction}

In 1985, the World Health Organization (WHO) set an optimal rate of $10-15 \%$ for caesarean birth to optimize maternal and child health, with the aim of reducing the disparity in caesarean birth rates among countries (1). Despite all the evidence regarding the risks and benefits of caesarean birth, there are still worldwide variations in its practice (2). The WHO Eastern Mediterranean Region is no exception to this, which has a maternal mortality rate of 166/100 000 live births (3). There is huge discrepancy in caesarean birth rates among the 22 Member States in the Region. Egypt, Islamic Republic of Iran and Lebanon have exceptionally high caesarean birth rates of $52 \%, 48 \%$, and $46 \%$, respectively, whereas Somalia and Afghanistan have extremely low rates of $<5 \%$ (Table 1 ) (4). Socioeconomic disparities among the Member States have influenced the uptake of health services by users but many believe that caesarean birth rate is affected by multiple contributing factors prevailing at individual, organizational and cultural levels. Numerous small studies have examined facility-based caesarean birth rates within the Member States (5-8). However, limited evidence is available on underlying determinants of caesarean birth trends both at national and regional levels. The health professionals, policy-makers, advisory bodies and public health communities have all expressed their concerns on this issue. The purpose of this paper is to review the available evidence on key underlying determinants of high and low caesarean birth rates within the Region.

\section{Methods}

A scoping literature review was performed to provide a descriptive analysis of the key factors responsible for extreme trends in caesarean birth rate in the WHO Eastern Mediterranean Region. The 22 Member States in the Region are classified into 3 groups based on the WHO recommended caesarean birth rate of $10-15 \%$ (Table 2) (4). We searched PubMed and Medline with keywords "determinants of caesarean birth/caesarean section" and "caesarean birth/caesarean section trend" in the Region during 2000-2017. To ensure that our search results were specific to the Region, we selected studies that included at least 1 Member State of the Region. We included, cohort studies, case-control studies, systematic reviews and review articles published in peer-reviewed journals both at the national and international level. The initial search returned 396 studies, of which, 58 met the above 
mentioned study criteria. The Islamic Republic of Iran had the highest number of studies that investigated caesarean birthrates, followed by Lebanon. Member States from Group 1 had the fewest studies and information about their demographics and socioeconomic indicators of maternal and child health care was extracted from their latest demographic health surveys, and health situational analysis reports. Relevant data for some Arab Member States [Qatar, Saudi Arabia, United Arab Emirates (UAE), Djibuoti, Kuwait, Tunisia, Palestine and Libya] were taken from their latest family health surveys (9-16). For Qatar and Pakistan we used evidence from collective review of their demographic health surveys (1990-2013). The population-based caesarean birth rates for Member States were extracted from the World Health Statistics 2015 (4). The identified key determinants were categorized and discussed according to the framework of healthcare utilization based on Andersen's Behavioral Model, first developed in 1968. It is the most widely acknowledged multilevel model that incorporates both individual and contextual determinants of health services use. The 3 major components of the model are predisposing factors, enabling factors and need factors $(17,18)$ (Figure 1).

\section{Results}

\section{Predisposing factors}

Women's age, education, parity, place of residence (urban/rural) and set of beliefs were identified as key predisposing factors responsible for the varying trend in caesarean birth rate in the WHO Eastern Mediterranean Region.

There was a positive association between maternal age at childbirth and having a caesarean section. A review of 3 demographic health surveys (1990-2002) from Jordan showed a positive association between maternal age $\geq 35$ years at birth and having a caesarean section (19). Similarly, in Egypt Kuwait, Lebanon, Qatar, Syrian Arab Republic, West Bank and Gaza Strip, and Bahrain, there was a $>5 \%$ disparity in caesarean birth rates between older and younger women. In Kuwait, for example, the caesarean birth rate among women aged $\geq 35$ years was $17.3 \%$ compared to only $4.8 \%$ among women aged $15-35$ years. This was in contrast to the UAE, which had higher caesarean section rates at younger ages, possibly due to the high rate of teenage pregnancy (20). A similar pattern was observed in Saudi Arabia; women aged $\geq 35$ years had a caesarean birth rate of $11 \%$ compared with $7 \%$ for younger women (16).

The likelihood of caesarean birth was high among women with high educational status. Egypt, Islamic Republic of Iran and Lebanon had the highest caesarean birth rates in the Region. In Egypt, the prevalence of caesarean birth in women with secondary education $(58 \%)$ was higher than in women with no education (37\%) (21-23). Saudi women with university education had increased prevalence of caesarean section compared with those who did not complete secondary school (10.5\% vs

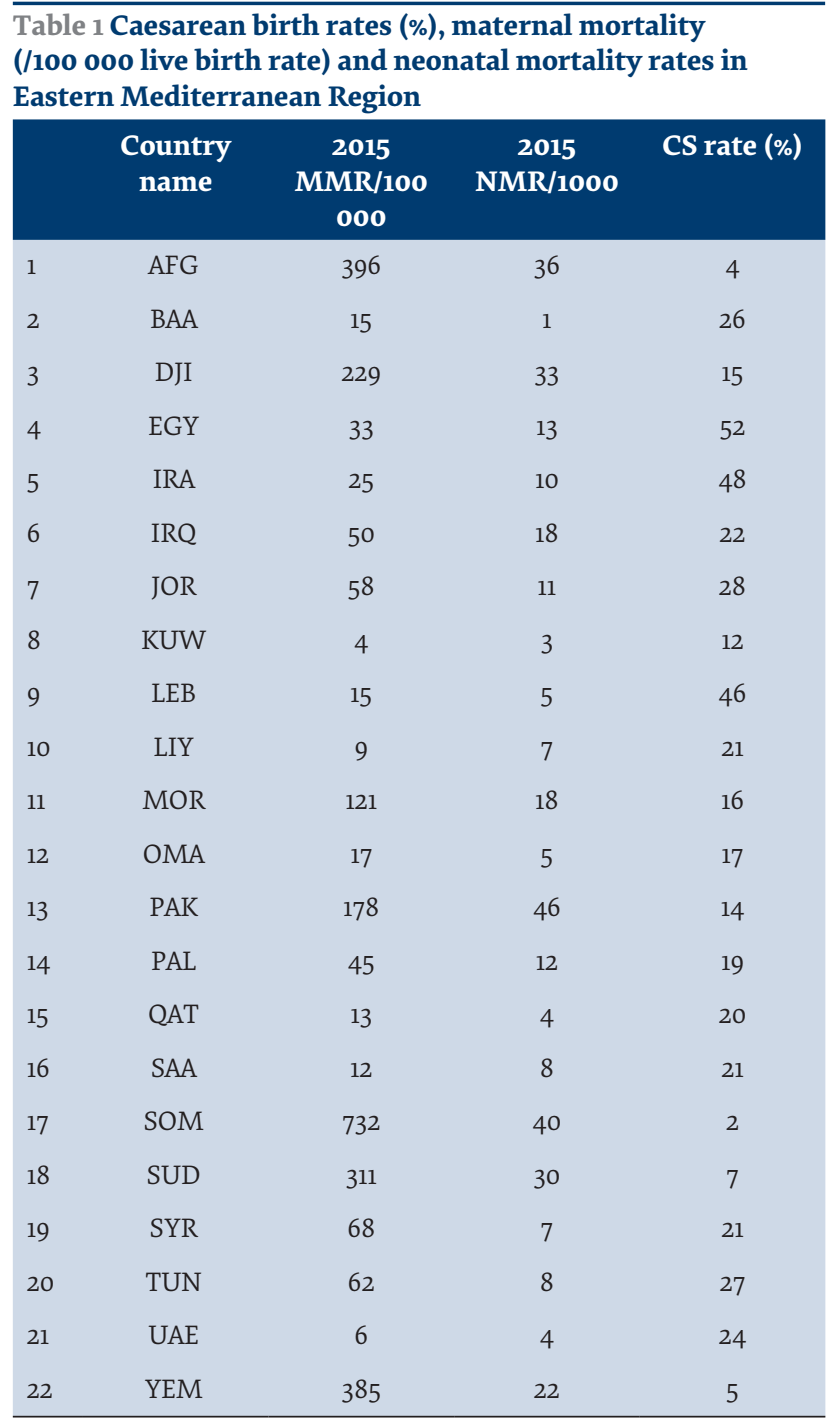

Source for CS rate: World Health Statistics 2015. Source for MMR: Trends in maternal mortality: 1990 to 2015: estimates by World Health Organization, United Nations (UN) Children's Fund, UN Population Fund, and World Bank Group. Source of NMR: Levels \& Trends in Child Mortality Reports 2015, estimates developed by the UN Inter-agency Group for Child Mortality Estimation. CS = caesarean section; $M M R$ = maternal mortality rate; $N M R=$ neonatal mortality rate.

\section{$8.5 \%)(24)$.}

High parity at birth was linked with an increase in repeat caesarean birth rate in Saudi Arabia and Iraq, where large families are the norm (25). This was in contrast to Egypt, where women with $<3$ live births were twice as likely to undergo caesarean birth than women with higher parity (26).

$\begin{gathered}\text { Table } 2 \text { WHO Member States divided into } 3 \text { groups according } \\
\text { to the WHO recommended caesarean birth rate (10-15\%) }\end{gathered}$
\begin{tabular}{cc}
\hline CB rates & Countries in Eastern Mediterranean Region \\
$<10 \%$ & Group 1: Afghanistan, Somalia, Sudan, Yemen (18\%) \\
$10-15 \%$ & Group 2: Djibouti, Kuwait, Pakistan (14\%) \\
$>15 \%$ & $\begin{array}{l}\text { Group 3: Bahrain, Egypt, Jordan, Iraq, Islamic } \\
\text { Republic of Iran, Lebanon, Libya, Syrian Arab } \\
\text { Republic, Tunisia, Palestine, Saudi Arabia, Morocco, } \\
\text { Oman, United Arab Emirates (68\%) }\end{array}$ \\
\hline $\mathrm{CB}=$ caesarean birth; WHO = World Health Organization.
\end{tabular}




Predisposing factors
Sociodemographic
variables
- Age
- Education
- Family size
- Place of residence
Health Beliefs

Evidence has suggested that high caesarean birth rate is common in women residing in urban areas. For example in Egypt, $60 \%$ of urban births were caesarean as compared to $48 \%$ in rural areas. The caesarean birth rate was also higher among women delivering in a private health facility than a government facility (66\% vs $45 \%$, respectively) (21). Member States that have higher rates of facility-based delivery have shown higher rates of caesarean birth. For example, Yemen and Sudan, with the lowest level of caesarean birth rate have low levels of urbanization and the lowest institutional delivery rate in the Region of only $15.5 \%$. This is in contrast to the Member States belonging to Groups 2 and 3 that have higher facility-based delivery rates and $>15 \%$ of caesarean birth rate. For example, in Bahrain the facility-based delivery rate is almost $100 \%(24)$.

Cultural norms and traditional health beliefs (e.g., attitudes toward health services, knowledge about disease, and cultural, social and family values) influenced women's choice of caesarean birth. The patriarchal nature of society in the Region, where decisions are made by husbands, fathers and mothers-in-law, is responsible for women's low decision-making power in seeking health care. In Group 1 Member States (Table 2), health-seeking behaviour is characterized by low confidence in modern medicine. The English word "surgery" means "slaughter" in Somali,

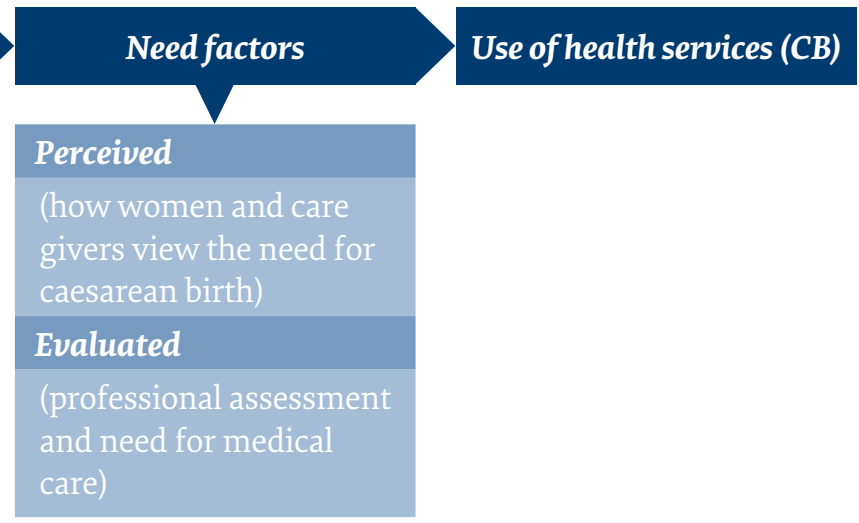

which is believed to contribute to the fear that women have of dying or losing their child during caesarean birth (27). This trend was reflected in the Afghanistan mortality survey that showed that, although antenatal care from a skilled provider had increased to $68 \%$, only $16 \%$ of women received $\geq 4$ antenatal visits (the minimum necessary to provide adequate screening for pregnancy complications (28).

\section{Enabling factors}

Enabling factors include financial and organizational factors that enable women to access and utilize healthcare services (Figure 1). WHO Eastern Mediterranean Region Member States from Group 1 (Table 2) with low socioeconomic status had low prevalence of caesarean birth (< $5 \%$ ). In Yemen, $98 \%$ of the women aged 15-49 years did not have any health insurance, and for specialized treatment like surgery, they spent up to a quarter of their annual household expenditure (29). In contrast, 14 Member States with caesarean birth rates $>15 \%$ were mainly highand middle-income countries. However, the relationship with socioeconomic status was not as straightforward as it seems. For example, Egypt, Islamic Republic of Iran, and Lebanon are all middle-income countries and had higher caesarean birth rates of $52 \%, 48 \%$, and $46 \%$, respectively, than Oman, Saudi Arabia, Kuwait and UAE had; all of 
which had better socioeconomic profiles (24). Such differences in the caesarean birth rate due to socioeconomic status have also been highlighted in individual Member States that have the highest rate of caesarean birth. For example, according to the 2014 demographic health survey of Egypt, two thirds of births among women in the highest wealth quintile were caesarean deliveries compared to $38 \%$ among women in the lowest wealth quintile (21). Similarly, the caesarean birth rate was significantly higher in Beirut-Mount Lebanon zone (high socioeconomic class with good access to health care) than in the rest of Lebanon (13.4\% vs. 7.6\%) (22). A similar pattern was observed in the Islamic Republic of Iran, with increased caesarean birth rate among women with high socioeconomic status (30). In contrast, another study in the Islamic Republic of Iran showed that, despite the obvious difference in total caesarean birth rate between various socioeconomic classes, there was no significant difference in socioeconomic status in non-emergency caesarean birth. The prevalence of elective caesarean birth has risen from $1.8 \%$ to $47.4 \%$ in the very poor to medium socioeconomic classes, showing that many other factors play an important role in the caesarean birth trend (31).

Organizational factors include variables such as the care process, human resources, capacity to provide safe caesarean birth and blood transfusion, and infrastructure of healthcare organizations. Various authors have established a strong link between the type of the health care facility (private/ government) and caesarean birth rate. According to a meta-analysis on prevalence and causes of caesarean birth in the Islamic Republic of Iran in 2014, private institutes had higher caesarean birth rates, reaching up to $87 \%$ in some cases (23). The caesarean section rate in private hospitals $(77.9 \%)$ in Iraq was markedly higher than the rate in public hospitals (29.3\%) (32). Lebanon, Jordan and Egypt had similar trends and suffered from dominance of the private health sector (19,33-35). Egypt had a 60\% facility-based delivery rate in private hospitals that undermines the authority of government sectors to standardize obstetric care (35). This is in contrast to Yemen, which had a low facility-based delivery rate, where only 1 in 10 births took place in private health facilities (29).

The low rate of caesarean birth among Member States in Group 1 is a reflection of low access to comprehensive emergency obstetric and neonatal care (EmONC) that includes all basic emergency obstetrics and neonatal care signal functions (mainly life-saving steps for mother and baby at birth) plus caesarean birth and blood transfusion (36). A demographic health survey from Yemen in 2013 showed that $42 \%$ of maternal deaths occurred at home, or in a relative's home and $19 \%$ on the way to a health facility, in comparison to $39 \%$ that took place in a health facility. The main reasons cited for home delivery were cost $(25 \%)$, distance to travel $(24 \%)$ and poor treatment by health providers $(9 \%)(29)$.

The shortage of skilled birth attendants (accredited midwives, doctors, nurses and obstetricians) was highlighted as a major barrier to achieving high rates of facility-based delivery in low-income countries. According to the latest data, only $20 \%$ of births in Sudan, $45 \%$ in Yemen, $46 \%$ in Afghanistan and 9.4\% in Somalia were attended by skilled birth attendants (37). These countries exhibited correspondingly high maternal and neonatal mortality rates. The Member States with high caesarean section rates lacked structured midwifery programmes that are essential to promote normal labour during childbirth. The resulting over-medicalization of normal labour can increase the risk of having a caesarean birth. A systematic review using the national data of African countries showed that skilled delivery attendance in Egypt, Tunisia, Djibouti and Libya was associated with significant reduction of maternal, fetal and neonatal mortality (38).

Uptake of caesarean birth is supply induced and thus strongly dependent on the capacity of healthcare systems to provide safe emergency obstetric services. A cross-sectional study in Afghanistan on availability and utilization of EmONC at 78 first-line referral facilities showed that $42 \%$ of peripheral facilities did not perform all 9 signal functions required for comprehensive EmONC, and treated only $20 \%$ of women expected to experience direct complications (39). Situational analysis of reproductive health in Somalia in 2009 indicated that for facility-based deliveries in hospitals, quality of care was low, either lacking or with outdated protocols for standard interventions during normal childbirth, such as the use of oxytocic drugs (40).

\section{Need factors}

Need for caesarean birth is when the expected health benefits to the mother and her baby outweigh the potential risks. This risk-benefit analysis is likely to be context dependent, since the safety of caesarean birth and its available alternatives varies across settings (41). According to Andersen's Behavioral Model both perceived and evaluated needs affect health service use (Figure 1). The perceived need for caesarean birth (how women and caregivers view the need for caesarean birth) is commonly associated with women's common misconception that caesarean birth is safer than vaginal birth for the baby (21). Women in Lebanon and the Islamic Republic of Iran blamed fear of pain during vaginal birth as a major factor in opting for caesarean birth $(23,42)$. A study conducted in Iraq showed that $11 \%$ of caesarean sections in a public hospital in Baghdad were conducted for nonmedical reasons such as fear of vaginal delivery (45.7\%), avoiding delivery pain (14.3\%) and a wish to have tubal ligation at the same time $(8.6 \%)$ (43). Clinicians perceived that the need for women to have a caesarean birth was due to their fear of litigation, time convenience and financial gain, which contributed to exceptionally high caesarean birth rates in the Islamic Republic of Iran, Lebanon and Egypt $(31,33,35)$.

The evaluated need represents objective measurement of women's health status and their need for medical care. The global cost of the needed caesarean sections in 2008 was estimated to be US\$ 432 million. If all the resources currently devoted to excess caesarean sections could be 
directed towards countries where additional procedures are needed, the needed procedures could be fully financed (44). Among WHO Eastern Mediterranean Region Member States in Group 3 (Table 2), previous caesarean birth ( $36.29 \%$ average) and fetal distress (18.86\% average) were the major reasons for caesarean section performed for clinical-midwifery reasons in the Islamic Republic of Iran (23). In Jordan, Egypt and Oman, previous caesarean birth, fetal malpresentation, failure to progress in labour, fetal distress, twins and preterm delivery were common clinical indications for performing caesarean section (45-47). Obesity, which has shown an increased prevalence in women in the Region, has also shown a significant positive association with caesarean birth rate in Member States like Iraq that have a high prevalence of high body mass index $(48,49)$. Obstructed labour and fetal malpresentation are the most prevalent indications for caesarean birth among Member States that lack access to caesarean delivery (50).

\section{Discussion}

This review highlights inequalities in access to and use of caesarean birth among the Member States of the WHO Eastern Mediterranean Region. Member States in Group 3 (Table 2) with high caesarean birth rates are mostly middle- and high-income countries. Egypt, Lebanon, Islamic Republic of Iran, Jordan and Pakistan have doubled their caesarean birth rates in the last decade $(20,51)$. Women's wealth index in these Member States has been strongly associated with their tendency to have a caesarean birth. Caesarean birth rates ranged from $5.5 \%$ in the poorest women to $35.3 \%$ in the richest according to the latest review of 3 demographic health surveys in Pakistan (19992013) (51). This observation is in line with the evidence provided by other studies indicating that caesarean birth is more likely in privately insured women as compared with women with public health insurance. Financial incentives associated with private insurance may encourage healthcare providers to perform more caesarean births (52). However, when this relationship was further explored, the caesarean birth preference among women in the high-wealth quintiles was linked to their misconception that caesarean birth is less painful for the mother and safer for the baby as compared to vaginal birth $(21,24,53)$. This is despite the evidence endorsed by internationally recognized bodies such as WHO, National Institutes of Health, and American College of Obstetricians and Gynecologists that caesarean birth is associated with adverse maternal and neonatal outcomes $(54,55)$.

In the present review, women's education emerged as a strong predictor of caesarean birth; a finding consistent with many other studies $(23,51)$. However, when confounders like age, marital status and parity were adjusted, the influence of high educational status was reversed and more-educated women were less likely to have a primary caesarean birth with weak clinical indications (56). Women were more likely to give birth with a skilled attendant present, and therefore more likely to survive childbirth.
We may conclude that perhaps socioeconomic status of the country is a more important determinant of caesarean birth rate than the women's individual socioeconomic characteristics.

Clinicians' preference for caesarean birth has significantly influenced women's decision to choose caesarean birth. The clinicians' role in overmedicalization of normal labour, and their tendency to take advantage of women's concerns about potential complications of childbirth, have been highlighted in various studies. Many clinicians believe that the lower tariff set for specialists in charge of vaginal birth increases their tendency towards performing caesarean births (33). Apart from financial incentives, practice of defensive medicine and professional convenience factors have urged clinicians to offer planned caesarean birth to women $(57,58)$. Lack of evidence-based guidelines regarding childbirth practice at national level and profitmotivated institutional settings, especially in the private sector, are leading to high caesarean birth rates. Reduced midwifery input in childbirth has led to a gradual shift from hospitals (labour in a comfortable place with trusted people and supporting companion) to high technology and time-limited obstetrics practice (if delivery is not within a given time frame, then caesarean section is performed). This increases the anxiety of both physicians and mothers, with increased tendency towards caesarean birth (59).

Evidence regarding the effect of demographic factors like increased maternal age, place of residence, place of birth, parity and obesity on high caesarean birth rates in the Region is inconsistent. Older women have an increased risk of fetal anomalies and maternal diabetes and hypertension, which has resulted in an increase in caesarean section in the Region. Also, fertility treatment is higher among older women, so they have a greater risk of pregnancy complications, leading to increased rate of caesarean section. This observation is in line with studies conducted in other parts of the world (60).

We found a high caesarean birth rate in women with obesity, which was consistent with the evidence that obese women were 6 times more likely than non-obese women to have caesarean birth due to cephalopelvic disproportion or failure to progress in labour $(47,61)$. The most common evaluated need for women to have caesarean birth was a previous history of caesarean birth. This is in contrast to other developed countries where attempted vaginal birth is offered as an acceptable, safe approach in women with a history of caesarean birth. In Lebanon such safe practice accounts for only $7 \%$ of deliveries. Such a low rate of attempted vaginal birth indicates that women who undergo primary caesarean section are more likely to go through repeated caesarean sections in Lebanon due to the refusal of most physicians to perform a vaginal birth after caesarean section (33). The increased incidence of clinical indications for caesarean birth could be a sign of serious health concerns among women but these indications must be properly evaluated and monitored by the standard WHO Robson 
Classification to determine their true contribution (62). High caesarean birth rate with no major improvement in maternal and neonatal health reflects the fact that women undergoing caesarean section are not the ones who need it most.

Evidence from Group 1 Member States (Table 2) revealed that shortage of skilled birth attendants and low access to safe caesarean birth are the 2 main factors contributing to low caesarean birth rates (38). A systematic review explored the relationship between maternal and neonatal mortality and deliveries attended by skilled health personal (including caesarean birth) in 41 African countries (38). This showed that an increase in caesarean birth rate (probably indirectly an increase in proportion of skilled person attended deliveries) was correlated with a reduction in maternal mortality rate. Similar regression lines were observed in the correlation analyses of stillbirth and neonatal mortality rates with the caesarean birth rate.

Multiple nonclinical factors (e.g., education, income, culture, religion, geographic inaccessibility, and lack of transport) also contributed to the high maternal and perinatal mortality. Consistent with prior studies in low-income countries, our findings showed that lack of women's empowerment for their health issues resulted in inappropriate health-seeking behaviour. The traditional home health practice with prayers and extra help from traditional healers was classed as their first option. Other studies claimed that $88-99 \%$ of maternal deaths could be avoided if women were able to reach existing emergency obstetric care rapidly (63). Even if one can overcome the access factor, most facilities in the Member States do not have sufficient surgical capacity for a procedure like caesarean birth, which is consistent with findings from low-income countries in other regions (64). Lack of caesarean birth services is known to increase the risk of maternal and fetal complications due to obstructed labour (65). In Afghanistan, 79\% of facilities in the observed time period provided caesarean birth, but only $74 \%$ provided blood transfusion. The facilities cited lack of human resources (77\%), lack of equipment and/ or supplies $(31 \%)$, and need for training $(15 \%)$ as the main reasons for not performing caesarean births (39).

The policy implications of our findings are as follows. caesarean section rate is an important indicator of accessibility to emergency obstetric care. To strengthen universal health coverage and equity in maternal health care it is important to optimize the caesarean section rate. Therefore, detail knowledge of underlying determinants of high and low caesarean birth rates in the Region is crucial for policy-makers to suggest the appropriate evidence-based interventions. This review highlights the complex nature of these determinants, suggesting that a multidimensional approach will be required in future through collaborative work between various sectors for optimization of caesarean birth rates.

Unlike most publications focusing on 1 extreme of the caesarean birth trend in the Region, our review provides a descriptive analysis of the underlying determinants of over- and underuse of caesarean birth in the Region. Although it was not an exhaustive review, we focused on papers that reported studies from the Region. In this process, however, we were challenged with the significant lack of good quality research on caesarean birth trends and their underlying determinants. The data from Group 1 Member States were limited in terms of quantity and quality; therefore, we relied on the information available from their respective health surveys. Most of the studies from other Member States were also small facility-based studies as opposed to population-based studies that would have given a better representation of the whole population.

In conclusion, our review highlights the inequity in the use of caesarean birth among Member States of the Eastern Mediterranean Region. Lack of access to facilitybased delivery and absence of skilled birth attendants during childbirth were the major underlying factors for the suboptimal caesarean birth rate in the Region. In contrast, the social, cultural and institutional factors, mainly affecting women's choice for caesarean birth, contributed to the higher caesarean birth rate in Member States in Groups 2 and 3 compared to Group 1. Further, carefully designed, qualitative studies are needed to explore how these factors affect the choice of birthing process in specific cultural settings of this Region. The country-specific factors should be taken into account for future studies to give a better understanding of these determinants.

Funding: None.

Competing interests: None declared.

\section{Déterminants du recours excessif et insuffisant aux accouchements par césarienne dans la Région de la Méditerranée orientale : analyse mise à jour \\ Résumé}

Contexte: La Région OMS de la Méditerranée orientale montre une disparité considérable dans les pratiques de naissances par césarienne au sein de ses 22 États Membres. Un nombre limité de recherches ont été effectuées au niveau régional pour déterminer les causes sous-jacentes.

Objectif : Examiner les données disponibles sur les principaux déterminants des taux faibles et élevés de naissances par césarienne dans la Région. 
Méthodes : Une étude exploratoire de la littérature a été réalisée. Nous avons effectué une recherche sur PubMed et Medline avec les mots-clés « déterminants des naissances/accouchements par césarienne » et « tendance des naissances/ accouchements par césarienne » dans la Région pendant la période 2000-2017. Nous avons inclus les études de cohorte, les études cas-témoin, les analyses systématiques et les examens publiés dans des revues à comité de lecture. Les dernières données sur les indicateurs démographiques et socio-économiques des soins de santé maternels et infantiles ont été extraites d'enquêtes démographiques sur la santé et d'analyses de situation réalisées par les États Membres ainsi que des statistiques de l'OMS pour 2015. Cinquante-sept (57) études sur un total de 395 répondaient aux critères d'inclusion. Ces déterminants ont fait l'objet d'examen dans un cadre conceptuel basé sur le modèle comportemental d'Andersen d'accès aux soins de santé, 2001.

Résultats : Les causes principales d'un faible taux de naissances par césarienne dans la Région sont l'inaccessibilité aux établissements pratiquant des accouchements et l'absence d'accoucheuses qualifiées. Des facteurs sociaux, culturels, individuels et institutionnels affectant le choix des femmes en matière d'accouchement ont également contribué à un taux de naissances par césarienne élevé.

Conclusion : Une approche pluridimensionnelle est requise afin d'analyser ces déterminants et en vue d'optimiser le taux de naissances par césarienne dans la Région. Des études qualitatives supplémentaires sont nécessaires pour étudier l'incidence de ces facteurs sur le choix du processus d'accouchement dans des contextes culturels spécifiques de la Région.

$$
\begin{aligned}
& \text { مُححدِّدات إفر اط وتدني استخدام الو لادات القيصرية في إقليم شرق المتوسط : استعر اض مُحدَّث } \\
& \text { بسمين جادون، رامز مهايني، كريمة الغلبزوري }
\end{aligned}
$$

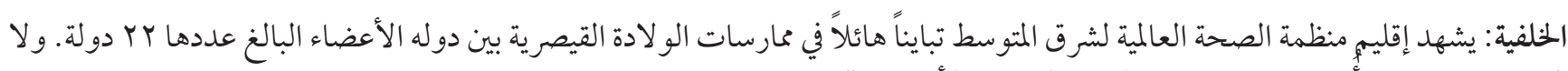
تكاد تو جد بحوث أجريت على مستوى الإقليم لتحديد الأسباب المجاب الكامنة. الأهداف: هدفت هذه الدراسة إلى استكشاف ما يوجد من أدلة على المُحدِّدات الرئيسية لارتفاع وانخفاض معدلات الو لادة القيصرية في الإقليم.

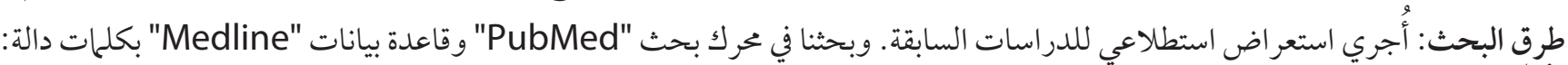

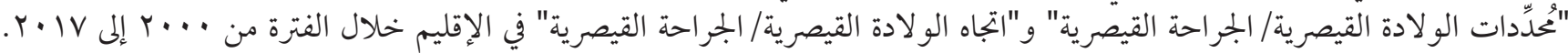

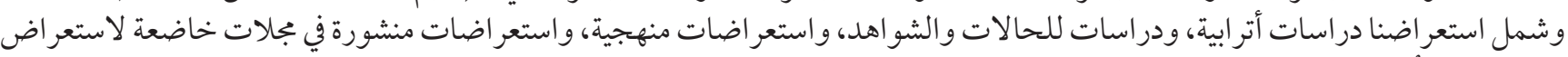

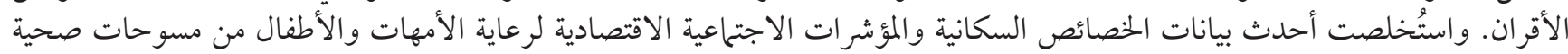

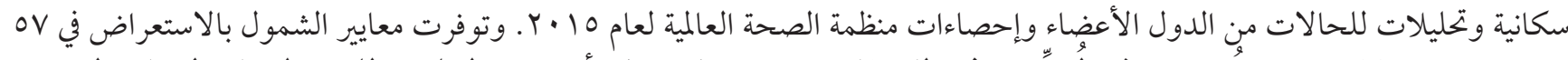

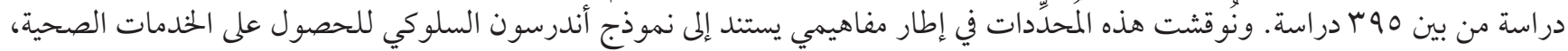
. r...

النتائج: كان انخفاض معدل الو لادات القيصرية في الإقليم يرجع إلى قلة فرص الو لادة في مرافق الرعاية الصحية وعدم وجود قابلات ماهر ات. كما

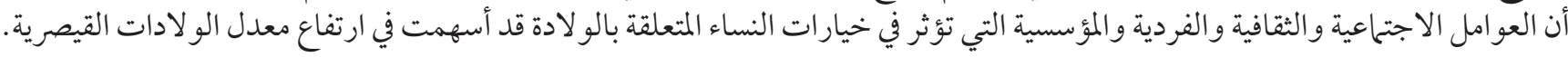

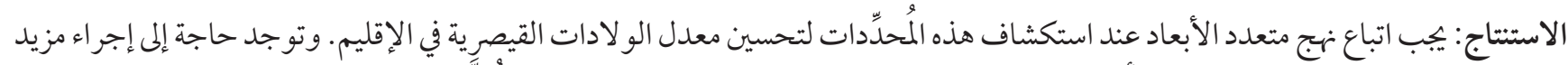
من الدراسات النوعية لاستقصاء كيفية تأثير هذه العوامل في خيار ات عملية الو لادة في بيئات ثقافية مُحدَّدة في الإقليم.

\section{References}

1. Appropriate technology for birth. Lancet. 1985 Aug 24; 2(8452):436-7 PMID:2863457

2. Betrán AP, Ye J, Moller A-B, Zhang J, Gülmezoglu AM, Torloni MR. The increasing trend in caesarean section rates: global, regional and national estimates: 1990-2014. PLoS One. 2016 Feb 5; 11(2):e0148343. http//dx.doi.org/10.1371/journal.pone.0148343 PMID:26849801

3. Trends in maternal mortality: 1990 to 2015, Estimates by WHO, UNICEF, UNFPA, World Bank Group and the United Nations Population Division. Geneva: World Health Organization; 2015 (http://www.who.int/reproductivehealth/publications/monitoring/maternal-mortality- 2015/en/, accessed 2 May 2019).

4. World Health Statistics 2015. Geneva: World Health Organization; 2015 (http://www.who.int/gho/publications/world_health_statistics/2015/en/, accessed 2 May 2019).

5. Ehtisham S, Akhtar Hashmi H. Determinants of caesarean section in a tertiary hospital. J Pak Med Assoc. 2014 Oct;64(10):1175-8. PMID:25823160

6. Badakhsh MH, Seifoddin M, Khodakarami N, Gholami R, Moghimi S. Rise in cesarean section rate over a 30-year period in a public hospital in Tehran, Iran. Arch Iran Med. 2012 Jan;15(1):4-7. http://dx.doi.org/012151/AIM.004 PMID:22208435 
7. Moini A, Riazi K, Ebrahimi A, Ostovan N. Caesarean section rates in teaching hospitals of Tehran: 1999-2003. East Mediterr Health J. 2007 Mar-Apr;13(2):457-60. PMID:17684866

8. Akasheh HF, Amarin V. Caesarean sections at Queen Alia Military Hospital, Jordan: a six-year review. East Mediterr Health J. 2000 Jan;6(1):41-5. PMID:11370339

9. Arab Fund for Economic and Social Development (AFESD), Arab Gulf Program for Development (AGFUND), Central Statistical Organization (Qatar), Health Ministers' Council for GCC States, Ministry of Public Health (Qatar), United Nations Children's Fund (UNICEF), United Nations Population Fund (UNFPA), United Nations Statistics Division (UNSD), World Health Organization (WHO). Qatar Family Health Survey, 1998.

10. Health Ministers' Council for GCC States, Ministry of Health (Kuwait), United Nations Statistics Division (UNSD). Kuwait Family Health Survey, 1996.

11. Health Ministers' Council for GCC States, Ministry of Health (United Arab Emirates). United Arab Emirates Family Health Survey, 1995 .

12. League of Arab States, National Center for Disease Control (Libya), Pan Arab Project for Family Health (PAPFAM). Libya Family Health Survey, 2007.

13. League of Arab States, National Office for Family and Population, Ministry of Public Health (Tunisia), Pan Arab Project for Family Health (PAPFAM). Tunisia Family Health Survey, 2001.

14. Department of Statistics and Demographic Studies (Djibouti), League of Arab States, Ministry of Health (Djibouti), Pan Arab Project for Family Health (PAPFAM). Djibouti Family Health Survey, 2002.

15. League of Arab States, Palestinian Central Bureau of Statistics, United Nations Children's Fund (UNICEF). Palestine Family Health Survey, 2006-2007.

16. Arab Fund for Economic and Social Development (AFESD), Arab Gulf Program for Development (AGFUND), Gulf-Co-operation Council (GCC), Ministry of Health (Saudi Arabia), United Nations Children's Fund (UNICEF), United Nations Population Fund (UNFPA), United Nations Statistics Division (UNSD), World Health Organization (WHO). Saudi Arabia Family Health Survey 1996-1997.

17. Andersen RM. Families' use of health services: a behavioral model of predisposing, enabling and need components [thesis] West Lafayette, In: Purdue University; 1968 Available from: http://docs.lib.purdue.edu/dissertations/AAI6902884/, accessed 2 May 2019).

18. Andersen RM, Davidson PL. Improving access to care in America: individual and contextual indicators. In: Andersen RM, Rice TH, Kominski EF, editors. Changing the U.S. health care system: key issues in health services, policy, and management. San Francisco: Jossey-Bass;2001:3-30.

19. Khawaja M, Al-Nsour M. Trends in the prevalence and determinants of caesarean section delivery in Jordan: evidence from three demographic and health surveys, 1990--2002. World Health Popul. 2007 Dec;9(4):17-28. PMID:18567949

20. Khawaja M, Choueiry N and Jurdi R, Hospital-based caesarean section in the Arab region: an overview. East Mediterr Health J. 2009 Mar-Apr;15(2):458-69. PMID:19554995

21. Ministry of Health and Population (Egypt), El-Zanaty and Associates (Egypt), ICF International. Egypt Demographic Health Survey, 2014. Cairo: Ministry of Health and Population; Rockville, MD: ICF International (https://dhsprogram.com/pubs/pdf/FR302/ FR302.pdf, accessed 2 May 2019).

22. Carayol M, Zein A, Ghosn N, Du Mazaubrun C, Breart G. Determinants of caesarean section in Lebanon: geographical differences. Paediatr Perinat Epidemiol. 2008 Mar;22(2):136-44. http://dx.doi.org/10.1111/j.1365-3016.2007.00920.x PMID:18298687

23. Azami-Aghdash S, Ghojazadeah M, Dehdilani N, Mohammadi M, Asl Amin Abad R. Prevalence and causes of cesarean section in Iran: systematic review and meta-analysis. Iran J Public Health. 2014 May;43(5):545-55. PMID:26060756

24. Jurdi R, Khawaja M. Caesarean section rates in the Arab region: a cross-national study. Health Policy Plan. 2004 Mar;19(2):101-10. PMID:14982888

25. Al Rowaily MA, Alsalem FA, Abolfotouh MA. Cesarean section in a high-parity community in Saudi Arabia: clinical indications and obstetric outcomes. BMC Pregnancy Childbirth. 2014 Feb 28;14:92. http://doi.org/10.1186/1471-2393-14-92 PMID:24575731

26. Yassin K. Saida G. Levels and determinants of caesarean deliveries in Egypt: pathways to rationalization. Internet J World Health Societal Politics. 2012;7(2)

27. Deyo NS. Cultural traditions and the reproductive health of Somali refugees and immigrants [thesis]. University of San Francisco; 2012 (https://repository.usfca.edu/cgi/viewcontent.cgi?article=1034\&context=thes, accessed 9 May 2019).

28. Afghan Public Health Institute, Ministry of Public Health (APHI/MoPH) (Afghanistan), Central Statistics Organization (CSO) (Afghanistan), ICF Macro, Indian Institute of Health Management Research (IIHMR) (India), World Health Organization Regional Office for the Eastern Mediterranean (WHO/EMRO) (Egypt). Afghanistan Mortality Survey 2010. Calverton, MD: APHI/ MoPH, CSO, ICF Macro, IIHMR, WHO/EMRO; 2011 (https://dhsprogram.com/pubs/pdf/fr248/fr248.pdf, accessed 2 May 2019).

29. Ministry of Public Health and Population (MOPHP), Central Statistical Organization (CSO) (Yemen), Pan Arab Program for Family Health (PAPFAM), and ICF International. Yemen National Health and Demographic Survey 2013. Rockville, MD: MOPHP, CSO, PAPFAM, ICF International; 2015 (https://dhsprogram.com/pubs/pdf/FR296/FR296.pdf, accessed 2 May 2019). 
30. Bakhtari F, Nadrian H, Matlabi H, Sarbakhsh P, Bidar M. Personal, interpersonal, and organizational predictors of the mode of delivery among urban women: a prospective study with socio-ecological approach. Clin Nurs Res. 2017 Oct 1:1054773817740530. http://dx.doi.org/10.1177/1054773817740530 PMID:29090590

31. Davari M, Maracy M, Ghorashi Z, Mokhtari M. The Relationship between socioeconomic status and the prevalence of elective cesarean section in nulliparous women in Niknafs Teaching Centre in Rafsanjan, Iran. Womens Health Bull. $2014 J u l ; 1(2):$ e20044. http://dx.doi.org/10.17795/whb-20044

32. Shabila, Nazar P. Rates and trends in caesarean sections between 2008 and 2012 in Iraq. BMC Pregnancy Childbirth. $2017 ; 17: 22$. http://dx.doi.org/10.1186/s12884-016-1211-6 PMID:28077096

33. Kabakian T, Kaddour A, DeJong J, Shayboub R, Nassar A. The policy environment encouraging C-section in Lebanon. Health Policy. 2007 Sep;83(1):37-49. PMID:17178426

34. Kabakian-Khasholian T, Shayboub R, El-Kak F. Seeking maternal care at times of conflict: the case of Lebanon. Health Care Women Int. 2013;34(5):352-62. http;//dx.doi.org/10.1080/07399332.2012.736570 PMID:23550947

35. Crane Linn E. Born by knife. In Egypt, C-sections are sold as the only way to give birth. Middle East Eye. 23 October 2015 (https:// www.middleeasteye.net/features/born-knife-egypt-c-sections-are-sold-only-way-give-birth, accessed 2 May 2019).

36. Hirose A, Borchert M, Niksear H, Alkozai AS, Cox J, Gardiner J, et al. Difficulties leaving home: a cross-sectional study of delays in seeking emergency obstetric care in Herat, Afghanistan. Soc Sci Med. 2011 Oct;73(7):1003-13. http://dx.doi.org/10.1016/j. socscimed.2011.07.011. PMID:21862194

37. WHO Global Health Workforce Statistics: December 2018 update. World Health Organization, Geneva; 2019 (https://www.who. int/hrh/statistics/hwfstats/en/, accessed 9 May 2019).

38. Berhan Y, Berhan A. Skilled health personnel attended delivery as a proxy indicator for maternal and perinatal mortality: a systematic review. Ethiop J Health Sci. 2014 Sep; 24 Suppl:69-80. PMID:25489184

39. Kim YM, Zainullah P, Mungia J, Tappis H, Bartlett L, Zaka N. Availability and quality of emergency obstetric and neonatal care services in Afghanistan. Int J Gynaecol Obstet. 2012 Mar;116(3):192-6. http://dx.doi.org/10.1016/j.ijgo.2011.10.017 PMID:22196990

40. Sorbye IK. A situation analysis of reproductive health in Somalia April 2009. United Nations Population Fund, World Health Organization, United Nations Children's Fund; 2011 (https://www.unicef.org/somalia/health_11703.html, accessed 2 May 2019).

41. Cavallaro FL. Measuring the unmet need for caesarean sections in sub-Saharan Africa and South Asia [thesis]. London: London School of Hygiene \& Tropical Medicine; 2015 (http://researchonline.lshtm.ac.uk/2172946/, accessed 2 May 2019).

42. Kabakian-Khasholian T. 'My pain was stronger than my happiness': experiences of caesarean births from Lebanon. Midwifery. 2013 Nov;29(11):1251-6. http://dx.doi.org/10.1016/j.midw.2012.09.001. PMID:23415357

43. Habib HA, Abdulla MM, Yacoub SE. Knowledge and preference of mothers delivering at ALKadhumyia Teaching Hospital regarding caesarean section and normal vaginal delivery. Iraqi Postgrad Med J. 2011;10(4):512-8. https://www.iasj.net/iasj?func=fulltext\&aId $=50282$

44. Gibbons L, Belizan JM, Lauer JA, Betran AP, Merial $\neg$ di M, Althabe F. Inequities in the use of cesarean section deliveries in the world. Am J Obstet Gynecol. 2012 Apr;206(4):331 e1-19. http://dx.doi.org/10.1016/j.ajog.2012.02.026 PMID:22464076

45. Hindawi IM, Meri ZB. The Jordanian caesarean section rate. Saudi Med J. 2004 Nov;25(11):1632-5. PMID:15573191

46. Helal AS, Abdel-Hady ES, Refaie E, Warda O, Goda H, Sherief LS. Rising rates of caesarean delivery at Mansoura University Hospital: a reason for concern. Gynecol Obstet. 2013;3:146. http://dx.doi.org/10.4172 /2161-0932.1000146

47. Al Busaidi I, Al-Farsi Y, Ganguly S, Gowri V. Obstetric and non-obstetric risk factors for cesarean section in Oman. Oman Med J. 2012 Nov;27(6):478-81. http://dx.doi.org/10.5001/omj.2012.114. PMID:23226819

48. Musaiger AO. Overweight and obesity in Eastern Mediterranean Region: prevalence and possible causes. J Obesity. 2011:Article ID 407237. http://dx.doi.org/10.1155/2011/407237

49. Al-Kubaisy W, Al-Rubaey M, Al-Naggar RA, Karim B, Mohd Noor NA. Maternal obesity and its relation with the caesarean section: a hospital based cross sectional study in Iraq. BMC Pregnancy Childbirth. 2014 Jul 17;14:235. http://dx.doi.org/10.1186/14712393-14-235 PMID:25034025

50. Dumont A, de Bernis L, Bouvier-Colle MH, Breart G; MOMA Study Group. Caesarean section rate for maternal indication in sub-Saharan Africa: a systematic review. Lancet. 2001Oct 20;358(9290):1328-33. PMID:11684214

51. Mumtaz S, Bahk J, Khang YH. Rising trends and inequalities in cesarean section rates in Pakistan: evidence from Pakistan Demographic and Health Surveys, 1990-2013. PLoS One. 2017 Oct 17;12(10):e0186563. http://dx.doi.org/10.1371/journal.pone.0186563. PMID:29040316

52. Hoxha I, Syrogiannouli L, Braha M, Goodman DC, da Costa BR, Jüni P. Caesarean sections and private insurance: systematic review and meta-analysis." BMJ Open. 2017 Aug 21;7(8):e01660o. http://dx.doi.org/10.1136/bmjopen-2017-016600 PMID:28827257

53. Barros AJ, Santos IS, Matijasevich A, Domingues MR, Silveira M, Barros FC, et al. Patterns of deliveries in a Brazilian birth cohort: almost universal cesarean sections for the better-off. Rev Saude Publica. 2011 Aug;45(4):635-43. PMID:21670862

54. American College of Obstetricians and Gynaecologists Committee on Obstetric Practice. Cesarean delivery on maternal request. Obstetr Gynecol. 2019 Jan;133(1):e73-7 ( https://www.acog.org/-/media/Committee-Opinions/Committee-on-Obstetric-Practice/ co761.pdf?dmc $=1 \&$ ts $=20190502 \mathrm{~T} 1351292993)$. 
55. National Institutes of Health state-of-the-science conference statement: Cesarean delivery on maternal request March 27-29 2006. Obstet Gynecol. 2006 Jun;107(6):1386-97. PMID:16738168

56. Gilbert A, Benjamin A, Abenhaim HA. Does education level influence the decision to undergo elective repeat caesarean section among women with a previous caesarean section? J Obstet Gynaecol Can. 2010 Oct;32(10):942-7. PMID:21176302

57. Arrieta A. Health reforms and cesarean sections in the private sector. The experience of Peru. Health Policy. 2011 Feb; 99(2):12430. http://dx.doi.org/10.1016/j.healthpol.2010.07.016 PMID:20724019

58. Shareat M, Majlasei F, Azarei S, Mahmodei M. Cesarean section rate and its determinants in maternity hospitals in Tehran. Payesh. 2002;1(3):5-10 (in Persian).

59. Yazdizadeh B, Nedjat S, Mohammad K, Rashidian A, Changizi N, Majdzadeh R. Cesarean section rate in Iran, multidimensional approaches for behavioral change of providers: a qualitative study. BMC Health Serv Res 112011 Jul 5;11:159. http://dx/doi. org/10.1186/1472-6963-11-159 PMID:21729279

6o. Lin HC, Sheen TC, Tang CH, Kao S. Association between maternal age and the likelihood of a cesarean section: a population-based multivariate logistic regression analysis. Acta Obstet Gynecol Scand. 2004 Dec;83(12):1178-83. http://dx.doi.org/10.1111/ j.0001-6349.2004.00506.x PMID:15548152

61. Young TK, Woodmansee B. Factors that are associated with caesarean delivery in a large private practice: the importance of pre-pregnancy body mass index and weight gain. Am J Obstet Gynecol. 2002 Aug;187(2):312-32. PMID:12193918

62. Betrán AP, Vindevoghel N, Souza JP, Gülmezoglu AM, Torloni MR. A systematic review of the Robson Classification for Caesarean Section: (2014) what works, doesn't work and how to improve it. PLoS One. 2014 Jun 13;9(6):e97769. http://doi.org/10.1371/ journal.pone.0097769 PMID:24892928

63. Knight HE, Self A, Kennedy SH. Why are women dying when they reach hospital on time? A systematic review of the 'third delay'. PLoS One. 2013 May 21;8(5):e63846. http://dx.doi.org/10.1371/journal.pone.0063846 PMID:23704943

64. Ologunde R, Vogel JP, Cherian MN, Sbaiti M, Merialdi M, Yeats J. Assessment of cesarean delivery availability in 26 low- and middle-income countries: A cross-sectional study. Am J Obstet Gynecol. 2014 Nov;211(5):504e.1-12. http://dx.doi.org/10.1016/j. ajog.2014.05.022 PMID:24844851

65. Wall LL. Obstetric vesicovaginal fistula as an international public-health problem. Lancet. 2006 Sep 30;368(9542):1201-9. http:// dx.doi.org/10.1016/So140-6736(06)69476-2 PMID:17011947 